\title{
Factors of Inverstment Efficiency and Attractiveness: The Case of Petrochemical Companies
}

\author{
Bondarenko Tatiana Grigorievna, Zhdanova Olga Aleksandrovna, Dyuzhov Alexey \\ Vladimirovich
}

\begin{abstract}
The paper describes the process of development of the petrochemical industry in the Russian Federation, which is comprehensively presented in the document"Strategy for the development of the chemical and petrochemical complex for the period up to 2030", the Government defines the future priorities and targets of the petrochemical industry. It analyses the real conditions for the favorable development of this strategy, it describes the existing prerequisites for the implementation of this type of the forecast. It outlinesthe close relationship between the development of the petrochemical industry and the formation of investment projects. It highlights the conditions for the optimal content of detailed design documentation. The author emphasizes the growth and development of the investment potential of the industry in this case. Investments in petrochemical projects will also be profitable for all participants in the investment process.
\end{abstract}

Keywords: government strategy, investment activity, petrochemical companies, petrochemical market, investment project, innovative development of the industry

\section{INTRODUCTION}

The effectiveness of investment projects implies that project results are consistent with the goals and interests of their participants (Ermilova et al., 2018). A project is considered economically efficient if it can ensure the return of invested capital within a reasonable time and generate certain income (Bibarsov et al., 2017)

Currently there has been a large number of theoretical (Burlakova, 2011), methodological (Dobrova et al., 2018) and applied research (Luebeck \& Petrov, 2018) on setting development strategies for petrochemical complexes. This is due to changing trends, tools, development tendencies, and approaches to the financing of petrochemical projects in Russia and worldwide.

This topic of the study is very relevant in view of the current geopolitical challenges for Russia, forcing to diversify the simple export of hydrocarbons and to more actively systematically develop the still far behind gas processing and petrochemical sectors in Russia (Takhumova et al., 2018).

\footnotetext{
Revised Version Manuscript Received on 16 September, 2019.

* Correspondence Author

Bondarenko Tatiana Grigorievna, Plekhanov RussianmUniversity of Economics,

Zhdanova Olga Aleksandrovna, Plekhanov Russian University of Economics,

Dyuzhov Alexey Vladimirovich, Plekhanov Russian University of Economics,

e-mail: t.g.bondarenko@gmail.com
}

Fundamental works by Russian scientists, "World Petrochemical Industry", "Study of the state and prospects of oil and gas processing and petro-chemistry in the Russian Federation" by Professor O.B. Braginsky, and "Development strategy of oil and gas Companies" by Professor K.N. Milovidov are also worth mentioning.

\section{METHODS}

The methodology of the study is based on the principles of the dialectic approach. The research relies on general scientific methods, including, observation, gathering factual evidence, analysis and synthesis, deduction and induction, classification, the comparative method, the method of analogies, the Delphi technique and quantitative methods, particularly the economic and mathematical methods, diagram andstatistical methods, and process modeling. The information base of the study comprises federal laws and subsequent regulations on the evaluation of the innovation-led development in companies, statistical data contained in the documents of the Federal State Statistics Service; information from annual financial statements of Russian and international oil and gas companies.

The country material in the study, being the basis of the analytical work, is presented to the extent that it allows us to characterize the main trends, which decisively determine the development of the oil and gas industry in Russia and in the countries of the world.

\section{DEVELOPMENT OF THE PETROCHEMICAL INDUSTRY IN THE RUSSIAN FEDERATION}

The development of the petrochemical industry in Russia is fully represented in the document "The Strategy for the development of the chemical and petrochemical complex until 2030", where the Government determines the future priorities and target indicators of the petrochemical industry (http://strategy2030.midural.ru/sites/default/files/files/strateg iya_him_i_neftehim_do_2030.pdf)

The petrochemical industry is among the highly efficient sectors of international business. Modern petrochemical industries, the products of which are new materials, many of which have unique properties, gradually bring humanity closer to a new technological structure, which can be called materials science.

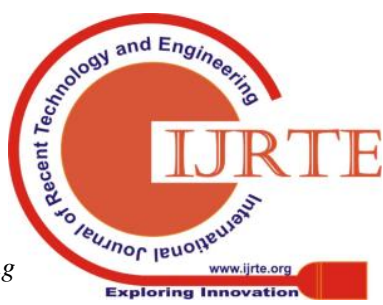


Working closely with the oil and gas complex, the petrochemical industry provides excellent examples of the rational use of hydrocarbon resources and the production of high value-added products.

Until this document appears the Russianpetrochemical marketcould be mentioned as the market of complex and expensive processes, which are not market goods. It is complicated by infrastructure issues and pricing complexity, and has a limited set of raw materials sources. All this allows to conclude on the weak investment and innovation position of petrochemical companies. Petrochemicals and polymer raw materials processing are far from being the strategic focus of most gas and oil refining companies, as the investments in such projects are high and EBITDA in absolute terms is incomparably lower than the revenues from operating income. Thus, petrochemical production can most commonly be considered just a part of an integrated development project, whose economy may currently be unprofitable, mainly due to high investments in deep gas processing and petrochemistry. The petrochemical industry can be called a value multiplier. Moving along the process chain from raw materials to petrochemical intermediates, petrochemicals, polymers and polymer products, in the petrochemical industry there is an increase in value up to 8-15 times the cost of the feedstock.

Factors negatively affecting the activities of organizations in the provision of mechanisms for financing investment projects in petrochemical companies are:

- high cost of resources;

- the imperfection of the regulatory framework of the industry;

- high level of taxation;

- opacity of petrochemical companiesactivity.

The petrochemical market is becoming increasingly globalized market in terms of the diffusion of new technologies, the availability of raw materials and markets; companies in the industry are faced with common problems, such as legislative regulation, pricing, and the reduction in the amount of "heavier" raw materials. Nevertheless, in view of different starting positions and historically developed strengths and weaknesses, the future of petrochemistry in different regions varies significantly.

The established recently economic situation in the country over the period analysed resulted in the need for restructuring economic policies, exploring new methods of financing and redirecting the country's economy, and for import substitution and localization of goods and services, in particular. What is more, encouraging the development of real economy became one of the important topical issues.

Evaluation of investment project effectiveness should be based on common basic principles applicable to any type of project, regardless of its technical, technological, financial, industrial or regional characteristics:

- $\quad$ project review throughout its life cycle (estimated period) - from conducting pre-investment research up to project finish;

\section{$\bullet$} modelling cash flows, including all cash receipts and expenditures related to project implementation for the billing period, taking into account the possible use of different currencies;

- $\quad$ consistent conditions for comparing different projects (project variants);

the principle of positivity and maximum effect. In order for the investment project to be recognized effective from the investor's point of view, it is essential that the effect of its implementation is positive; when comparing alternative investment projects, the preference should be given to the project with the greatest effect value;

- time management. When evaluating the project effectiveness, various aspects of the time factor should be taken into consideration, including the dynamism (changing with time) of the project parameters and economic environment; temporal dislocation between the production or resources delivery and payment; time transgressive costs and / or results (preference for earlier results and later expenditures);

- $\quad$ accounting only the upcoming costs and revenues. When calculating performance indicators, only the costs and revenues coming up during project implementation should be accounted for, as well as the upcoming losses directly caused by project implementation (for example, suspension of the existing production due to organization of new production in its place). The previously acquired resources being used in the project are estimated by the opportunity cost, reflecting the maximum value of the lost profit in their best possible alternative use. Prior costs are not accounted for in cash flows and do not affect the value of performance indicators;

- "with the project" and "without the project" comparison. Evaluating investment projects efficiency should be carried out not by comparing the "before the project" and "after the project" situations, but the "without the project" and "with the project" ones;

- considering the impact of working capital requirement, necessary for the functioning of the production assets created during project implementation, on the efficiency of investment projects;

- $\quad$ inflation (accounting for changes in prices for various types of products and resources during project implementation) and the possibility of using several currencies in project implementation;

- the impact of uncertainties and risks in project implementation.

At this momentpetrochemistry serves a driver of hydrocarbons demand, and, as the international petrochemical industry shows, it is growing rapidly, due to the globally increased chemicalization of economy. Until 2030 , the advanced countries of the world plan to maintain the pace of development in the petrochemical industry at a rate of $7 \%$ at least per annum (see Figure 1,Figure 2). 


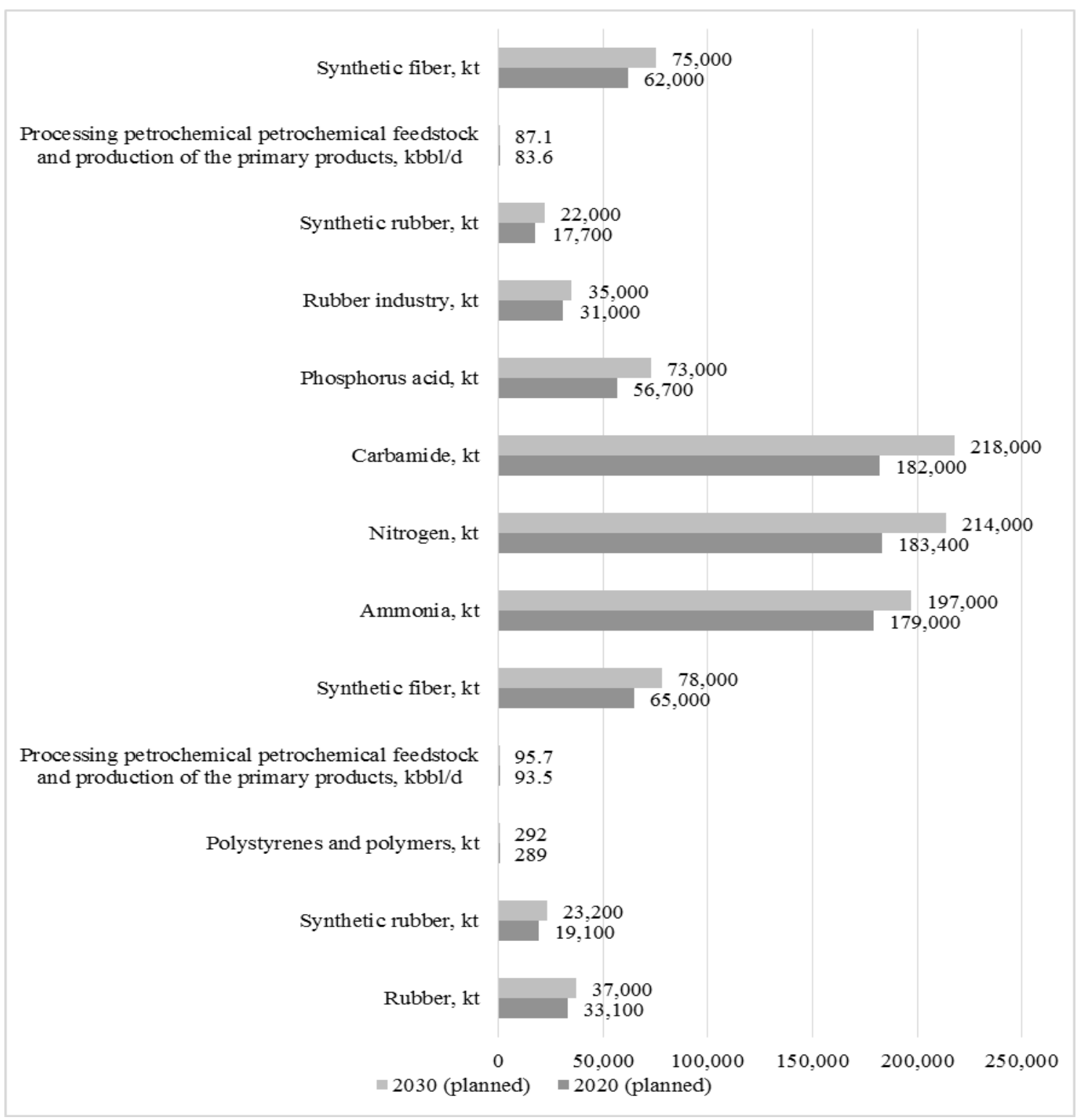

Figure 1. Production projections for the main market segments until 2030 (http://ac.gov.ru/files/publication/a/19162.pdf)

\section{Growth indicator, \%}

Synthetic fiber, kt

Processing petrochemical petrochemical feedstock and.

Synthetic rubber, kt

Rubber industry, $\mathrm{kt}$

Phosphorus acid, kt

Carbamide, $\mathrm{kt}$

Nitrogen, $\mathrm{kt}$

Ammonia, kt

Synthetic fiber, $\mathrm{kt}$

Processing petrochemical petrochemical feedstock and.

Polystyrenes and polymers, kt

Synthetic rubber, kt

Rubber, kt

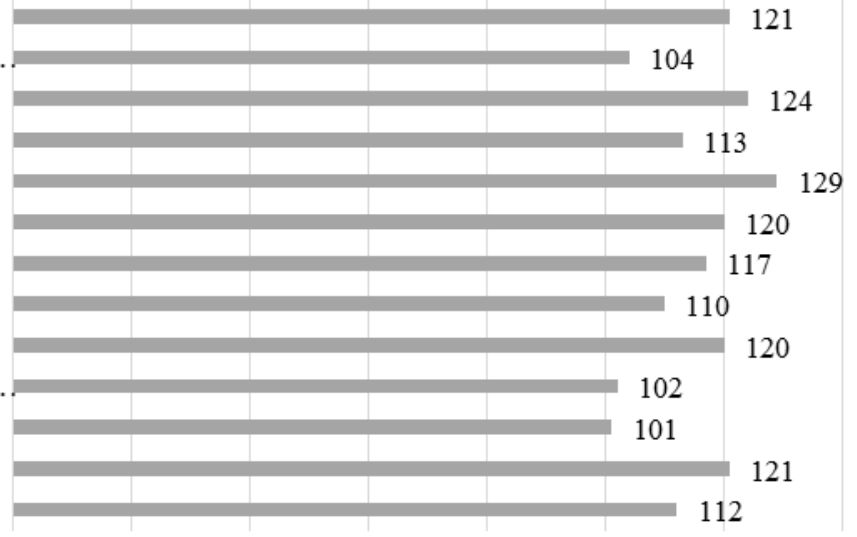

20

$40 \quad 60 \quad 80 \quad 100$

Figure 2.The forecast of growth indicators of the segments of the market "Petrochemistry" until 2030 (http://ac.gov.ru/files/publication/a/19162.pdf) 
In recent years, the petrochemical industry in Russia has achieved some success, due to increased investment and starting up several large-scale production facilities. In 2010-2017, the production of large-capacity polymers in Russia grew by 58\% and reached 5,4 million tons. The growth was ensured by investment increase in the industry and the commissioning of new large-scale industries

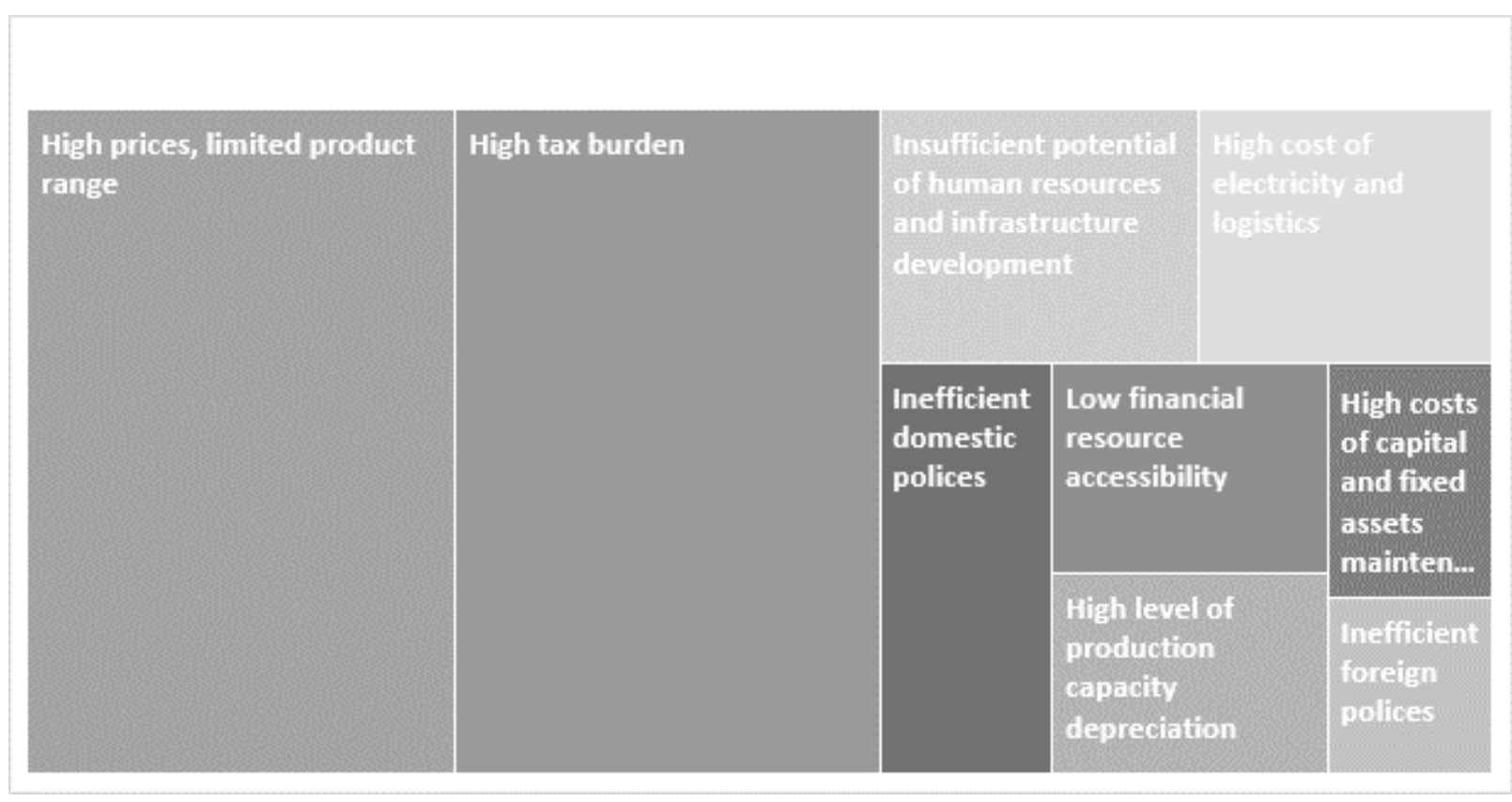

Figure 3. The degree of combined impact of individual segments of Russian petrochemical industry on the final index of competitiveness

and gas companies are letting their petrochemical sectors float

The tendency towards integration manifests itself in different ways in the global petrochemical complex. On the one hand, there has been an increase in integration (the formation of the petrochemical sectors of the largest oil and gas companies, the absorption of some companies by others). On the other hand, there are frequent cases of narrow specialization of companies, their focus on the production of certain types of products, for which these companies have serious competitive advantages. Wanting to focus on the upstream stage, some oil freely.

Thus, prioritization of problems according to the degree of influence of the main segments of petrochemical companies on competitiveness is presented in Figure 3.

The priorities in the development of the petrochemical industry in the Russian Federation until 2030, declared at the international conference "Gas and Petrochemical Industry 2030" are worth noting.(see Figure 4).

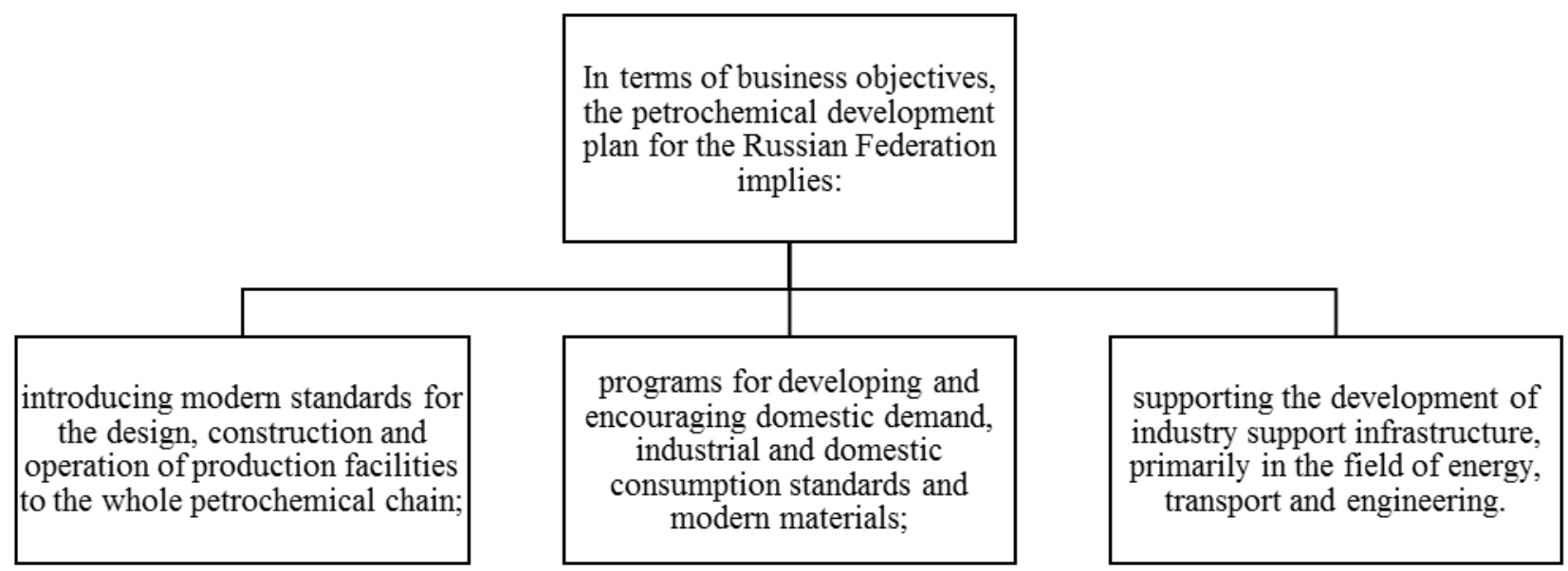




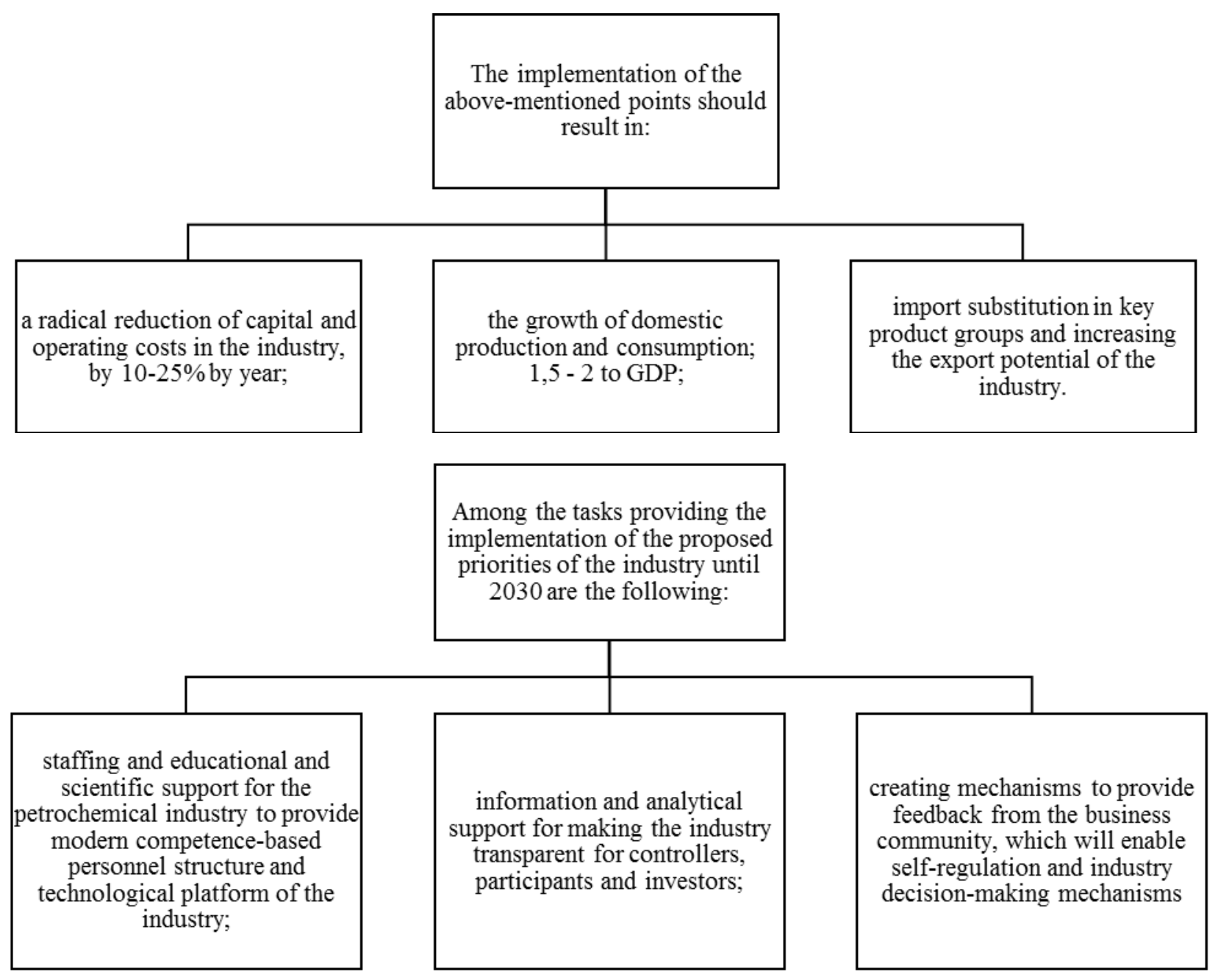

Figure 4. The priorities in the development of the petrochemical industry in the Russian Federation until 2030

Therefore, from this point of view, petrochemistry should be considered one of the top priority directions of Russian economy development.

It is also important to note that investment projects in the petrochemical industry are often long time and require a scheduled plan for project financing, traditionally a preliminary project schedule is drawn up in current prices. It is also important to note that investment projects in the petrochemical industry are often long time and require

The preliminary scheduled plan for project financing is a working document to be followed by the approved schedule of financing the project of investment activity. When working out the preliminary scheduled plan for project financing, the costs from the summary cost estimate of construction, in current prices, are distributed by types and quarters of the current year, with the exception of works performed by the production unit itself.

With a project implementation period of more than one year, the costs of subsequent periods are reflected in the financing schedule as a total sum by year of implementation, without a breakdown into quarters (Sucic et al., 2016). Next, the following approved schedule of financing the project is created (taking into account the increased/ changed cost items), which reflects the changes in construction costs throughout the entire period of project implementation.

To calculate the index of increased costs based on industry price indices (deflators), quarterly indices (deflators) are identified. When calculating the increased cost of capital investments, it is assumed that the rise in prices takes place gradually throughout the year. Thus, the calculated quarterly coefficients are identified by extracting the fourth root of the value of the annual index (deflator). For companies that do monthly planning, it is possible to use estimated monthly coefficients, which are determined similarly, by extracting the twelfth root of the value of the industry price index.

When arranging a scheduled plan for project financing for approving, the total capital expenditures in the corresponding quarters are multiplied by the corresponding values of quarterly indices (deflators).

The first quarter is the one, in which the decision on project implementation was made. At its beginning, the estimated cost is to be transformed in current prices, in the manner specified for the estimates, and then in scheduled planning, as the project progresses, the appreciation of the remaining estimated costs is based on quarterly indices (deflators).

As construction projects can be put into operation not only at the beginning or the end of the period, but also throughout the quarter, the calculations may require the index value (deflator) for the mid-quarter, which in this case is calculated as the arithmetic average between the quarterly index value (deflator) at the beginning of the quarter and at its end. Meanwhile, for the first quarter, after making the decision on project implementation, the index (deflator) is only half the value of the corresponding index (deflator) for the period. Additionally, it should be mentioned that if a project

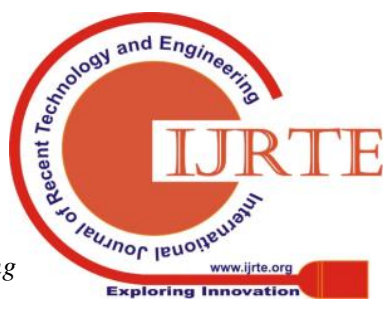


presupposes the purchase of imported equipment, then for correct cost planning, it is necessary to set aside some amount of capital expenditures for the purchase of imported equipment. To calculate the increase in the cost of equipment, it is necessary to use the price index of the US industry, and the price index of Russian industry to calculate the remaining part of the capital expenditures on the construction project (Tkacheva et al., 2017). In both cases, the calculation method will be identical; the only difference will be in price indices. After recalculating, the amounts with the cost increase are added up to get the total values of the target project costs for the relevant periods.
A similar approach will be applied in case of foreign contractors' involvement in the project.

The volume of capital expenditures while evaluating their cost at other stages of project consideration (project initiation, project study and justification of investment) is evaluated based on the price indices of the industry, similarly to the method described above. Meanwhile, the volume of investments in current prices is determined by analogues or through consolidated cost indices.

Favourable conditions for the development and growth of petrochemistry investment potential are presented in Figure 5.

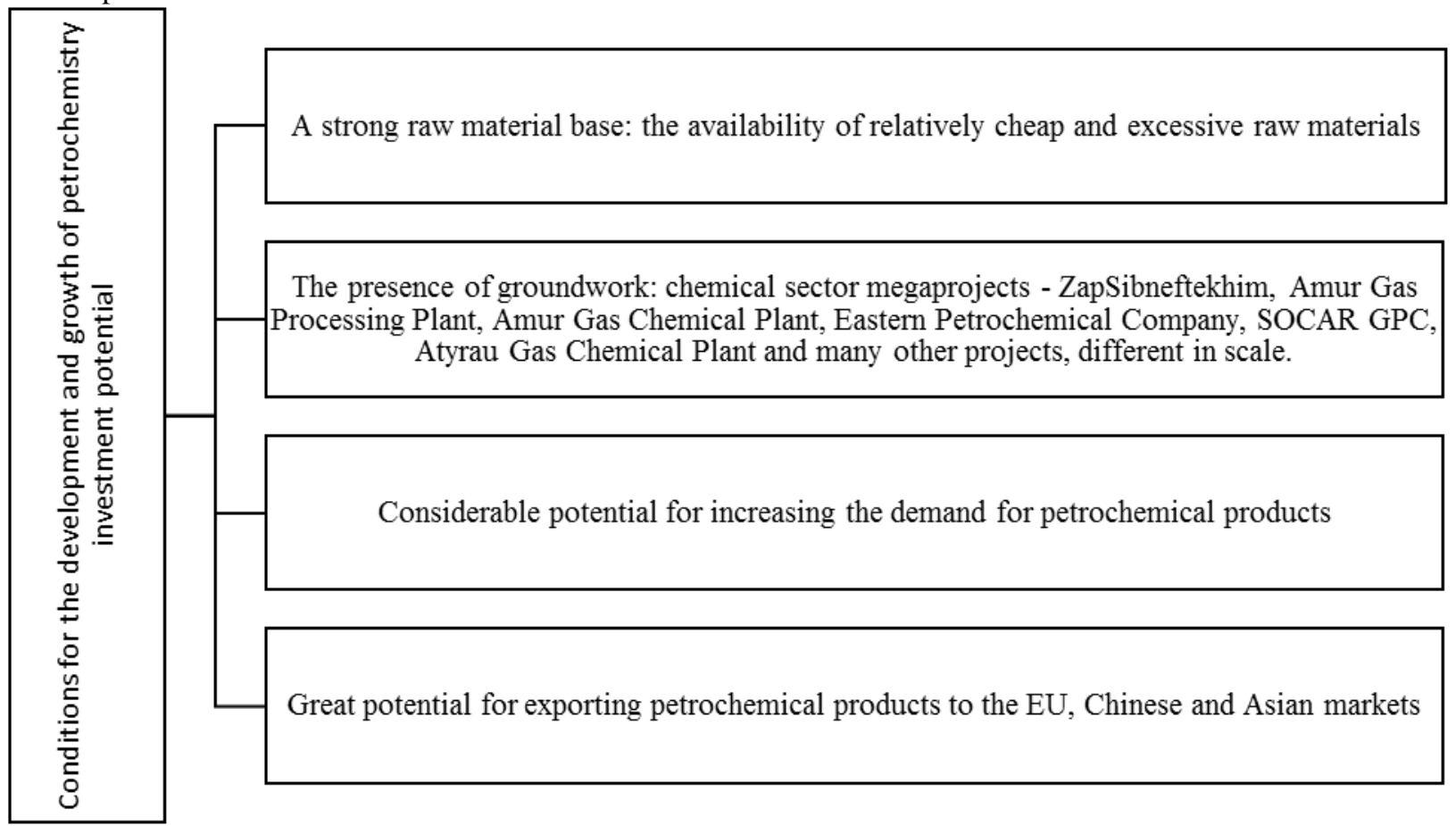

Figure 5. Favourable conditions for the development and growth of petrochemistry investment potential

Thus, financial organizations come to realization that this potential will be developed by all means, both at the state and corporate levels. The organizational optimization resources are limited, and manufacturers are at such a stage, when the proportion of new technologies in business is growing substantially, which will proceed in future. So, today, petrochemical companies need to decide, which technologies and solutions will provide the most profitable production and output with high added value, and which financing mechanisms will be most convenient and highly-demanded.

\section{DISCUSSION AND CONCLUSION}

Petrochemical companies will constantly be trying to find ways to run more projects at lower cost, adjust to the changing conditions, introduce innovations and increase business continuity through the use of advanced technologies and solutions for improving the profitability of chemical production and economic efficiency of innovation activity. Maximizing the profitability of investment projects and innovative projects, is possible due to optimization of raw materials in petrochemical production, according to the scenarios of changing the financial market situation.

In the paradigm of the new technological structure, there are some obvious project investments in petrochemical companies: the need to replace outdated equipment and to build new or reconstruct the existing oil pipelines. Such changes create ample opportunities and prospects for the use of modern financing technologies.

Consequently, consistent with all the above, it can be said that the development strategy of the industry and investment projects for petrochemical companies is the most important document. Thanks to this document a set of the optimal tools for attracting supplementary fundingappears in the industryfor petrochemical companies. Bearing in mind the ever-growing business volumes, and complying with the recommendations for growth of the companies in the industry until 2030, the financial mechanisms offered by the market are most profitable, relevant, simple and convenient to apply to practice, not to mention other numerous advantages and state support.Petrochemical investment is becoming transparent and profitable for all participants.

\section{REFERENCES}

1. Bibarsov, K., Khokholova, G., Okladnikova, D. (2017). Conceptual basics and mechanism of innovation project management. European Research Studies Journal, 20 (2): 224-235.

2. Burlakova, V.G. (2011). Energy management as an activation mechanism of innovative activity in the economy. Economics Industry, 54-55 (2-3): 198-206. 
3. Dobrova, K., Danilochkina, N., Cherner, N., Dobrov, V., Dobrov, P., Sepiashvili, E. (2018). Innovational management of industrial enterprises in the energy sector. European Research Studies Journal, 21 (1): 447-458.

4. Ermilova, M., Laptev, S., Ushakov, D. (2018). Financing the Russian housing market: problem and the role of the state. Opcion. 34:1074-1087

5. Luebeck, J., Petrov, D. (2018). Use of investment project implementation mechanism under production sharing agreement for the development of oil and gas. European Research Studies Journal. 21(1): 650-662

6. Petrochemistry as a driver for the hydrocarbons demand (2018). Available at: http://ac.gov.ru/files/publication/a/19162.pdf

7. Sucic, B., Al-Mansour, F., Pusnik, M., Vuk, T. (2016). Context sensitive production planning and energy management approach in energy intensive industries. Energy, 108: 63-73.

8. Takhumova, O., Kadyrov, M., Titova, E., Ushakov, D., Ermilova, M. (2018). Capital structure optimization in Russian companies: problems and solutions. Journal of Applied Economic Sciences. XIII , 7 (61): 1939-1944

9. The strategy for the development of the chemical and petrochemical complex until 2030. Available at: http://strategy2030.midural.ru/sites/default/files/files/strategiya_him_ i_neftehim_do_2030.pdf

10. Tkacheva, O.A., Tsurak, L.A., Getmanova, I.A., Chistyakov, A.V., Zakharov, S.V. (2017). New possibilities and tools for corporate strategic management for supporting its high competitiveness and economic effectiveness. European Research Studies Journal, B 20 (3): 578-587. 